Nataša Vlah, Ph. D., Associate Professor

Faculty of Teacher Education, University of Rijeka

natasa.vlah@uniri.hr

Darko Lončarić, Ph. D., Associate Professor

Faculty of Teacher Education, University of Rijeka

darko.loncaric@uniri.hr

Anamaria Brižan

Faculty of Teacher Education Alumna, University of Rijeka anamaria.brizan@gmail.com

\title{
SOCIAL CREATIVITY OF EARLY PRIMARY SCHOOL PUPILS AND BEHAVIORAL PATTERNS IN SCHOOL CONFLICTS ${ }^{1}$
}

\begin{abstract}
According to the theory of conflict resolution, in the school, as an educational institution, systematic influences on constructive social behaviors and quality choices are possible. The study aimed to determine the relationship between the creative potential of early primary school pupils and their patterns of behavior in school conflicts. Early primary school pupils $(N=73$; $55.1 \%$ girls) participated in the research by solving the EPoC-SOC test of potential social creativity. Their teachers $(N=16 ; 38-60$ years; $96 \%$ women) assessed three patterns of pupil behavior (winning, avoiding, and cooperation). Non-standardized results were used to assess divergent-exploratory thinking as well as convergent-integrative thinking in tasks with dyad social relations and group tasks. Correlation analysis found only a statistically significant negative association between the avoidance pattern and achievement on the tasks of convergent-integrative social creativity. The obtained results suggest the need for further research on the relationship between pupils'social competency and behavior in conflicts.
\end{abstract}

Keywords: EPoC, patterns of behavior in conflict situations, classroom teaching, social creativity

This work has been supported by the University of Rijeka under the projects number uniri-drustv-18-98 1233 and uniri-drustv-18-209 


\section{INTRODUCTION}

In the last few decades, increasing attention has been paid to creativity, especially since it has been perceived as an important life component of solving personal and professional problems (Lubart, Zenasni, Barbot, 2013). In this context, it is interesting to explore the social aspect of human creativity. In addition to intelligence, today, creativity is considered an equally important social virtue for the world of the future in which "intellectual societies" will be the foundation of the humanization of life (Srića, 1992; 2003). Quality education of future adult citizens implies an approach that emphasizes the socio-emotional ability to cooperate and constructively associate with others (Pekrun and Linnenbrink-Garcia, 2014). It also implies an approach to learning how to resolve disputes with others constructively. This arises as a natural consequence of communication between people of different opinions, attitudes, values, and desires (Vlah, 2013) so that, at a reproductively and economically mature age, today's children and tomorrow's responsible citizens could have creative collaboration skills. Such cooperation in the competitive conditions of the modern way of life requires creativity in social relations. Since very little is known about the relationship between social creativity and behavior in social conflicts, this paper analyzes the assumed relationship between these concepts in early primary school pupils. The assumption is thereby that, in school, as an educational institution, systematic influences on behavior and quality choices in social conflicts are possible.

\section{SOCIAL CREATIVITY}

In general, creative thinking is considered a specific way of solving problems (Torrance, 1965; 1993). One definition explains creativity as "a mental process by which a person creates new ideas or products, or combines existing ideas and products in a way that is new to them" (Vlahović-Štetić et al., 2005: 133). Although there is still no one unique definition of the complex concept of creativity, it is unquestionable that the value of ideas or products and their novelty are among the important features of creativity (Amabile, 1983; Sternberg and Lubart, 1992, 2001; Torrance, 1993; Sternberg, 2005; Kunac, 2015). Some authors point out that originality, an extremely rare ability to create unusual and unique ideas, is one of the most important features of creativity (Čudina-Obradović, 1991; Srića, 1992). In addition to originality, equally important characteristics of creative individuals include fluency and a sense of humor, openness to new experiences, risk-taking, self-confidence, non-conformism and autonomy, and perseverance (ČudinaObradović, 1991; Srića, 1992; Lubart, 1994; 2016; Arar and Rački, 2003; Kim, 2006). Talents, education, cognitive abilities, interests, and personality in integration result in creative ability and creative performance (Amabile, 1983; Besançon and Lubart, 2008, according to Barbot et al.,2011). Today, creativity is no longer 
explained as God's gift (Lubart, 1994) and creative individuals are not considered as the chosen ones, as it was considered in the 19th century (Kunac, 2015). Instead, it is believed that everyone is born creative, but only a few persevere (Arar and Rački, 2003; Kunac, 2015). Although many scholars still do not have a clear consensus on adequate procedures for developing creativity, they agree that the opposite process of reducing creative potential is more frequent because it involves less investment of time and energy in designing an adequate teaching process (Cvetković Lay and Sekulić Majurec, 2008). Creativity, with which everyone is born, to a certain extent, weakens during schooling (which is mostly focused on the correctness of procedures and correct and incorrect answers), and this is precisely the time when creativity in children should be encouraged the most (Sternberg and Lubart, 2001; Stenberg, 2005).

In this paper, we focus on social creativity because of its interpersonalism in social conflicts. The starting point is the assumption that interpersonal creativity, as one of the essential features of social creativity, refers to an individual's behavior in interaction with another person in everyday situations and exceptional and rare. It is a prerequisite for the functioning of the individual, the shaping of the ego, self-realization, and psychological health, but also leadership in general. As early as in 1968, Guilford emphasized the importance of social creativity and the need for it wherever problems arise, i.e., in everyday life (according to Mouchiroud and Lubart, 2002). Most authors approach the measurement of creativity theoretically within the framework of the cognitive approach. By applying such tests, the degree of creativity is assessed based on individual abilities of divergent thinking, fluency, flexibility, and originality that an individual achieves within a specific time (Barbot et al., 2011; Maksić, 2006; Arar and Rački, 2003; Lubart 2016). In such tests, the participants are encouraged to generate as many ideas as possible (Maksić, 2006).

The EPoC (Evaluation of Potential Creativity) test is a new creativity test designed by Todd Lubart, Maud Besançon, and Baptiste Barbot to measure creativity in children and adolescents (Barbot et al., 2011). For measurement purposes, the operational definition defines creativity as parallel processes of divergent and convergent thinking (Barbot et al., 2011). Unlike many previous creativity tests that most often measured the divergent thought process that is non-specific to the domain of creative action, $\mathrm{EPoC}$ measures the divergent-exploratory and convergent-integrative potential of an individual in the graphic, verbal, social, sciences, and mathematical domains (Jurišević, 2014). In this sense, the tasks of divergent thinking in the social domain require the production of as many different ideas as possible to solve a particular interpersonal task or challenge in a group or pair. In contrast, convergent types of tasks measure social creativity and encourage participants to create a unique, integrative solution to different interpersonal tasks or challenges also contextualized in peer relationships in a group or pair (Barbot et al., 2011). In Croatia, the social domain of creativity measured with the EPoC 
test has only just begun to be applied, and there are relatively few published papers with the results of such research. In one study, Grdinić and Lončarić (2018) examined whether there is a connection between social creativity and the stages of development of pupils' moral reasoning. A complex pattern of connectivity was established through relatively low negative correlations of results on the test of the development of moral reasoning and potential creativity in the social domain. Children who are more creative in the social domain gave answers characteristic of lower levels of moral reasoning. In the methodological limitations of that paper, it is pointed out that the obtained results must be additionally verified through replications and research conducted on larger samples of participants.

\section{BEHAVIORAL PATTERNS IN SOCIAL CONFLICTS}

Mutual diversity implies a diversity of perspectives, understandings, and actions in all areas of life. Their inconsistency is sometimes an inevitable result of personal disagreement and disagreement between two or more persons (Weeks, 2000). Conflicts are frequent and inevitable, regardless of the time and place of their occurrence (Wilmot and Hocker, 1998). Although often associated with negative connotations, conflicts are a significant segment of human life and communication. They exist at every level of interaction from personal to international conflicts, and intrapersonal, interpersonal, and group conflicts are distinguished accordingly (Deutsch et al., 2006; Bar-Tal, 2011).

Social conflict implies a mutual disagreement between two parties that simultaneously represent an obstacle to each other (Mitchell, 1989); it is a situation of apparent disagreement and divergence of worldviews between at least two people (Kriesberg and Dayton, 1992). It may also be considered a fight between at least two dependent parties based on a mismatch of goals and resources and the interference of others in their accomplishments (Wilmot and Hocker, 1998). Social conflict refers to a mutual dissatisfaction between two or more persons whose outcome, depending on their behavior, is resolved in favor of one individual, all of those involved, or no one (de Vliert, 1997; Vlah 2013; Uzelac and Bujušić, 2014; Ajduković and Pečnik, 2007). In addition to interpersonal relationships (Vlah, 2013), social conflict arises and is resolved in a communicative context. In other words, communication is a fundamental feature of behavior in conflicts (Wilmot and Hocker, 1998; Dunn, 2004; Ajduković and Pečnik, 2007; Vlah, 2013).

Patterns of behavior in conflicts are learned in the social environment of one's upbringing (Vlah, 2013), that is, in primary (e.g., parents, family), secondary (e.g., kindergarten, school), and tertiary (e.g., media, historical-geographical cultural determinism) environments and places of socialization. The growth and development of each individual in interaction with the environment shapes their personally acceptable way of coping and reacting in situations of social conflict, but the learned patterns are subject to change, depending on the assessment of their quality 
during life (Dunn, 2004; Puzić et al.,2011; Vlah, 2013; Vlah and Nikolić, 2020). Numerous classifications of behavior patterns in social conflicts are known in the literature, ranging from two to seven different patterns, depending on the theoretical concept from which the concepts and classifications arise (Vlah, 2013; Wilmot and Hocker, 1998). In this paper, we will use the classification of three patterns of behavior in conflicts that previous research (Družinec and Vlah, 2016; Vlah and Nikolić, 2020) found to be relevant for early primary school age: the pattern of winning, the pattern of avoidance and the pattern of cooperation.

Winning in social conflicts is an unconstructive pattern of behavior characterized by high self-care and almost insignificant care for others, which is why this pattern is also the most destructive pattern of behavior in social conflict situations (Wilmot and Hocker, 1998; Družinec and Vlah, 2016). The fundamental goal of a person who behaves victoriously is the realization of their own goals, desires, and intentions as well as victory, regardless of the damage inflicted on the opposing participant in the conflict (Weeks, 2000). The pattern of winning in situations of social conflict implies an unfair quarrel with the aim of revealing the weakness of the party to the conflict and the attempts to deceive them. It includes ironizing the interlocutor and malicious wit and is an example of abuse of conflict, whose consequences include mutual distancing of conflicting parties due to even more complicated relations between them, which is also an incentive to create new conflicts (Brajša, 1996). The superior party intentionally uses inappropriate superiority and competitive orientation, which prevents a mutually beneficial resolution of the social conflict (Wilmot and Hocker, 1998; Weeks, 2000; Uzelac and Bujušić, 2014). The pattern of winning may involve verbal aggression, but also mental and physical violent conflict resolution (Wilmot and Hocker, 1998). It is associated with violent behavior in interpersonal relationships and is more often used by socially incompetent persons (Vlah, 2013).

Avoidance in social conflicts is also an unconstructive pattern of behavior that is characterized by susceptibility to other people's goals in the absence of commitment to achieving one's own (Družinec and Vlah, 2016). It is sometimes used because, in the traditional understanding of social conflict, such conflict is socially undesirable, indecent, and socially unacceptable, so the result of such an understanding is avoidance (Brajša, 1996) and potentially suppression of constructive resolution of social conflict. Avoidance of social conflict in this sense is sometimes caused by the fear of confrontation and rejection of the social group to which one belongs, sometimes by a lack of self-esteem to confront or readiness for an uncomfortable situation in the process of negotiation in social conflict. However, this is mostly due to the belief that opposition is a form of undesirable behavior and that competition to achieve one's own goals is an unequal way of resolving social conflict for both opposing parties (Vlah, 2013; Weeks 2000). Apart from the fact that avoiding social conflict does not enable constructive resolution, but usually 
results in even more difficult conflict resolution or conflict escalation in the future, this behavior pattern does not allow for learning or personal progress (Uzelac and Bujušić, 2014; Weeks, 2000). In addition, avoiding social conflict increases the frustration of undesirable and unpleasant relationships, and such a situation encourages the emergence of a larger conflict than had existed at the beginning (Brajša, 1996; Weeks, 2000). Denying the existence of social conflict does not benefit any conflicting party, which is why this pattern of behavior is an ineffective pattern of behavior in terms of the long-term well-being of the participants of social conflict (Wilmot and Hocker, 1998; Vlah, 2013).

Cooperation in social conflicts is a constructive pattern of behavior that is opposite to the pattern of winning and is accordingly characterized by high collaboration and engagement, that is, special care for others and for oneself (Wilmot and Hocker, 1998), which requires maturity. Persons with a developed identity are able to meet their needs optimally, including social needs, without denying others the opportunity to meet their own (Glasser, 2000, according to Uzelac and Bujišić, 2014; Ivanova and Bikmetova, 2017). In other words, the degree of identity is a direct prerequisite for resolving social conflict. Brajša (1996) uses the term successful conflict for collaborative resolution of social conflicts, given that it is characterized by a fair, concrete, honest, and co-responsible discussion. This pattern of behaviour is not aimed at current disagreement but at a deeper understanding of the obstacles that have led to the conflict, and it thus enables the long-term building of a positive relationship between the conflicting parties and implies the use of communication and social skills to resolve conflicts and relationships (Weeks, 2000; Vlah, 2013). It is based on a partnership and implies an equal distribution of responsibilities and a creative finding of an appropriate solution for both parties (Wilmot and Hocker, 1998). A particularly important precondition for resolving social conflicts through a pattern of cooperation is creativity in finding various constructive solutions (Ajduković and Pečnik, 2007; Sternberg and Lubart, 2001). Although the pattern of cooperation requires much more time and effort in the realization of constructive resolution of social conflict, it also implies the absence of competition because the behaviour represented and promoted by the pattern of cooperation prevents the use of destructive and unconstructive patterns (Wilmot and Hocker, 1998; Vlah, 2013; Weeks, 2000; Družinec and Vlah, 2016). The consequences of cooperative, constructive behaviours in conflicts (such as active listening, respect for the other's opinion, self-regulation of emotions) are improved and deepened relationships between the conflicting parties, developed compassion and self-confidence. In contrast, subsequent conflicts for both parties are a form of more intensive communication aimed at achieving mutual benefit (Brajša, 1996). According to Weeks (2000: 23), the understanding of conflict as a positive potential for mutual development "encourages creative behaviour." 
Previous research has found that parents believe their children mostly, though not always, use the pattern of cooperation to achieve conflict resolution but almost never use the pattern of avoidance/adaptation and winning as a solution (Vlah et al., 2019; Vlah and Nikolić, 2020). Early primary school teachers, on the other hand, assess the pattern of cooperation as the most common, the pattern of avoidance as less common, and the pattern of winning as the least common among the pupils whose behavior was assessed (Družinec and Vlah, 2016). Girls are more prone to the pattern of cooperation than boys, who, in turn, are more prone to the pattern of winning. No gender differences have been found in the pattern of avoidance (Družinec and Vlah, 2016; Vlah and Nikolić, 2020).

Conflict management theory (Mitchell, 1989; Wilmot and Hocker, 1998; Weeks, 2000; Deutsch et al., 2006) implies the ability to creatively find multiple satisfactory solutions to achieve benefits for all parties to the conflict. In this theory, social creativity is implicitly stated as an essential component of constructive behavior in social conflicts, i.e., the choice of a constructive pattern of cooperation against non-constructive patterns of winning and avoiding. As has already been pointed out, primary schooling is an opportunity for social learning and the adoption of creative behaviors in constructive conflict resolution.

Insufficient tolerance and misunderstanding and a narrow-minded view of the conflict subject can play an important role in the course of conflict resolution (Brajša, 1996). Creative thinking makes it easier to solve everyday problems, thus connecting creativity with more acceptable patterns of behaviour that an individual uses in conflicts (Greene and Noice, 1998). An individual's behaviour in social conflict significantly depends on their skills and competencies, among which is creativity (Animasahun, 2008) but, according to Deutsch et al., (2006), personality is also involved.

Since the outcome of social conflict may (but does not have to) be psychologically and physically destructive for opposing parties, in education, it is important to keep in mind that skillful behaviour in social conflicts enables personal and social growth (Bar-Tal, 2011). In children, desirable behaviour in conflicts develops social skills and enables successful adaptation in the psychophysical sense. In adults, it enables constructive action and self-realization (Družinec and Vlah, 2016; Žitinski 2010). Knowing and understanding the different patterns of behaviour used in conflicts can raise awareness of individual ways of coping with opposing views, influence the change of one's own patterns of behaviour in conflicts, and prevent destructive conflicts (Vlah, 2013; Družinec and Vlah, 2016). The Decision on the adoption of the curriculum on the cross-curricular topic of personal and social development for primary schools and grammar schools in the Republic of Croatia (OG 7/2019), which aims to "encourage comprehensive development of children and youth, whose purpose is to build a healthy, confident, creative, productive, proactive, satisfied and responsible person capable of 
cooperation and contribution to the community," speaks in favor of the importance to nourish personal and professional growth in the contemporary school in Croatia.

This paper aims to determine the connection between the potential social creativity of early primary school pupils and their patterns of behaviour in school conflicts. Since the literature review did not find similar research on which to base working hypotheses, this is an exploratory study in which a connection between these concepts is expected based on two theories relevant to the assumed relations: (i) conflict resolution theory (Weeks, 2000; Wilmot and Hocker, 1998; Deutsch et al., 2006), which assumes the development of specific knowledge, traits, and skills for constructive patterns of behaviour in social conflicts and (ii) the socio-ecological theory of personal and social development of the child (Bronnfenbenner, 1979), which assumes different levels of influence on the child's personality and behavioural development, including the microlevel of primary school. The purpose of the research is to use the obtained data for future research also in the applied sense for the improvement of educational work in school, more specifically in the domain of pupils' personal and social development.

\section{METHODOLOGY}

A quantitative methodology was used to answer the research aims. Since the collected data did not meet the prerequisites of parametric analysis, the correlation between the variables was determined with the Spearman rank correlation coefficient. The differences between the groups of subjects were tested with the MannWhitney $U$ test to compare the two independent data sets. Pupils who participated in the test of potential creativity were selected using the method of a random sampling of pupils from the list in the "e-grade register". The teachers assessed the patterns of behaviour of these pupils in social conflicts.

\section{SAMPLE OF PARTICIPANTS}

The research comprised 73 pupils from the first to the fourth grade $55.1 \%$ of pupils, 6-10 years, $\mathrm{M}=8.58, \mathrm{SD}=1.19$ ), from three primary schools in Rijeka. Out of the total number of participants, 69 of them (the subsample does not differ from the basic sample in terms of demographic characteristics) successfully solved the EPoC test of social creativity. Analyses that establish a link between social creativity and teacher assessments of pupil behaviour in a conflict were conducted on that subsample.

Their early primary school teachers $(\mathrm{N}=16 ; 96 \%$ of female teachers, $38-60$ years, $\mathrm{M}=45.65$ years, $\mathrm{SD}=6.9$; work experience from 12 to 39 years, $\mathrm{M}=22.74$; $\mathrm{SD}=8.7$ ) gave assessments of pupil behaviour in conflicts. Early primary school teacher assessed the behaviour of four to five pupils from their class. 


\section{MEASURING INSTRUMENTS}

The EPoC test of potential creativity in the social domain (Lubart et al., 2011; 2018; Lončarić, 2018; Grdinić and Lončarić, 2018) determined the creative potential of early primary school pupils in that specific domain of creativity. The test taken by the pupils consists of four tasks from which a participant's scores of social creativity in interaction with another person (SCd; dyad relationship), in interaction with a group ( $\mathrm{SCg}$; creativity in a group), convergent-integrative $(\mathrm{CI})$ and divergent-exploratory (DE) score of social creativity, and the total score of social creativity (SC) are calculated. The time allotted to solve each task varies from 10 to 15 minutes, and the entire testing is conducted on two occasions between which a minimum interval of one week is desirable. Form A of the EPoC test of potential creativity in the social domain was used in this research. In order to facilitate the contextualization of the results, we provide conceptual frameworks for the four tasks: 1. task of divergent-exploratory thinking (dyad): "Create as many ideas related to a situation with your friend"; 2 . task of convergent-integrative thinking (group): "Design an action plan for a group of children"; 3. task of divergent-exploratory thinking (group): "Design as many ideas for a group of children"; 4. task of convergent-integrative thinking: "Design an activity plan for your friend."

Using the Scale of Assessing Patterns of Pupil Behavior in Conflict (Družinec and Vlah, 2016), teachers/ early primary school teachers assessed their pupils' behaviours in social conflicts. Teachers observed and assessed student behaviours using a Likert-type response format ( 1 - fully disagree, 2 - mostly disagree, 3 - neither agree nor disagree, 4 - mostly agree and 5 - fully agree). The Scale originally measured three patterns of children's behaviour in school. This study confirmed the three-dimensional structure of children's behaviour in school conflicts: a) pattern of winning in social conflicts $(\mathrm{k}=7$; Cronbach's alpha $=0.90), \mathrm{b})$ pattern of avoidance in social conflicts $(\mathrm{k}=7$; Cronbach's alpha $=0.85)$, c) pattern of cooperation in social conflicts $(\mathrm{k}=7$; Cronbach's alpha $=0.89)$.

\section{PROCEDURE}

Data collection using the $\mathrm{EPoC}$ test of potential social creativity and scoring the test for research purposes, was preceded by a training (Lončarić, 2018) for the administrators and evaluators of the children responses on convergent-integrative tasks. Training also covered administrative tasks related to organizing the testing and collecting the informed consent of the parent/guardian. Parents' informed consent was collected (out of 123 requested, 73 completed and signed consents were obtained). The research was conducted in accordance with the Code of Ethics for Research with Children (2003). In order to ensure the protection of participants' data and their identity, the research was conducted using codes. Prior to the start of the research, all participants and their parents were informed about the research purpose and methodology as well as about their right to withdraw from 
the research at any time. The schedule for conducting the research was agreed in advance with the school. Testing of creativity was conducted with each pupil on two occasions, with a one-week interval between the two sessions. After the research, all children's products were scanned and stored on Google-disk under a separate code of each participant, after which the scoring was performed. Scoring the tasks of convergent-integrative thinking was carried out with the consensus of two independent, trained evaluators.

The research was conducted in classrooms in schools attended by the research participants. Individual testing of pupils was conducted by an educated user of the EPoC test, who, during the testing, acted according to the given protocol and guided the participants through solving the tasks within the given framework. The time required to take the $\mathrm{EPoC}$ test of potential social creativity test was a maximum of 45 minutes for each pupil. In the period between the two tests, early primary school teachers assessed pupils' behaviour by filling out Teacher questionnaires, which, in addition to general data, contained the Scale of Assessing Patterns of Pupil Behaviour in Conflict (Družinec and Vlah, 2016). Teachers submitted the completed questionnaires to administrators, and the evaluators trained to conduct the $\mathrm{EPoC}$ test with the pupils.

After conducting the research, the evaluators assessed the participants' tests. Two trained evaluators conducted the process of assessing potential creativity. Scoring of divergent-exploratory thinking tests refers to the number of answers given by the participants, in accordance with the task and instructions. The work on the tasks of convergent-integrative thinking was first scored independently by the researchers, following the criteria adopted during the training, using a unique 7-degree scale (from 1 to 7). Then they agreed on the scores by consensus. Within the scoring of convergent-integrative thinking, the lowest points 1 and 2 are awarded to below-average creative works, 3, 4, and 5 denote different levels of average creative products, while 6 and 7 points are awarded to significantly above-average creative products. In doing so, the evaluators took into account the scoring rubrics, the criteria that the creative work must meet, examples from the manual, the Croatian socio-cultural context, the age of the child, but also the type of task being assessed.

\section{STATISTICAL METHODS}

Data collected with the EPoC test and the Scale of Assessing Patterns of Pupil Behaviour in Conflict were matched according to children's codes for further statistical processing. Results on the subscales of the Scale of Assessing Patterns of Pupil Behaviour in Conflict were calculated as the average linear composites of items belonging to a particular subscale (the sum of all items divided by the number of items for each of the three patterns). Descriptive statistics were determined for each subscale. Also, pupils' socio-demographic data (age, sex, grade) and 
evaluators' socio-demographic data (age, sex, and years of service) are provided. Due to the asymmetry of results on social creativity scores, the hypotheses about the relationship between social creativity results and patterns of behaviour in conflicts were tested using the nonparametric analysis. The Spearman rank correlation coefficient was used to determine the relationship between the variables, and the Mann-Whitney U test was used to test differences between groups. All analyses were performed in IBM SPSS 22.0 statistical software.

\section{RESULTS}

Descriptive results for individual tasks and social creativity scores are shown in Table 1, while the same indicators for patterns of behavior in social conflicts are shown in Table 2.

Table 1. Descriptive indicators on the results of individual tasks and on the composite scores of the EPoC test of potential social creativity

\begin{tabular}{|l|c|c|c|c|c|c|c|c|c|}
\hline & N & Min. & Max. & M & SD & Median & $\begin{array}{c}\text { Quartile } \\
\text { dispersion }\end{array}$ & symmetry & kurtosis \\
\hline Soc1Dd1 & 69 & 1 & 15 & 5.42 & 2.67 & 5 & 3 & 1.14 & 1.96 \\
\hline Soc2Cg1 & 69 & 1 & 7 & 2.96 & 1.34 & 2 & 2 & 0.83 & 0.06 \\
\hline Soc3Dg2 & 69 & 1 & 9 & 3.10 & 1.76 & 3 & 2 & 1.25 & 1.41 \\
\hline Soc4Cd2 & 69 & 2 & 7 & 2.93 & 1.13 & 3 & 1 & 1.47 & 2.25 \\
\hline DE & 69 & 2 & 22 & 8.53 & 3.86 & 8 & 4 & 1.26 & 2.43 \\
\hline KI & 69 & 3 & 12 & 5.89 & 2.12 & 5 & 3 & 0.86 & -0.13 \\
\hline
\end{tabular}

Index: $\quad$ Soc1Dd1 = first task - divergent-exploratory thinking (dyad) in the first measurement; Soc $2 \mathrm{Cg} 1$ = second task - convergent-integrative thinking (group) in the first measurement; Soc3Dg2 = third task - divergent-integrative thinking (group) in the second measurement; Soc4Cd2 = fourth task - convergent-integrative thinking (dyad) in the second measurement. $\mathrm{DE}=$ sum of points on divergent-exploratory tasks; $\mathrm{KI}=$ sum of points on convergent-integrative tasks

Composite scores related to the two divergent-exploratory social creativity tasks (DE; number of products from 0 to $\mathrm{N}$ ) and two convergent-integrative social creativity tasks (CI; assessments on a scale from 1 to 7) were calculated as a simple sum of the results on the tasks. On the other hand, the social creativity scores of an individual in interaction with another person ( $\mathrm{SCd}$; dyad relationship), in interaction with a group ( $\mathrm{SCg}$; creativity in a group), and the total scores of social creativity (SC) are expressed on tasks with different metrics and assessments of creativity). The stated scores cannot be calculated without standardization, and it is most appropriate to use them after test standardization. Since there are no Croatian norms for this test yet, these indicators were not calculated nor used in the further data analysis. 
It can be seen from Table 1 and the previous text that the results on individual tasks and scores are mostly positively asymmetrically distributed, which indicates the grouping of a larger number of results at lower values and a smaller number of high or very high results. All indicators have appropriate variability coefficients, with divergent tasks standing out as tasks with the highest variability coefficient and the ability to best differentiate children of different creative potential. This result may be partly related to the fact that some participants had extremely high results in divergent thinking measurements.

Table 2. Descriptive data for assessed early primary school pupils' patterns of behavior in social conflicts

\begin{tabular}{|l|c|c|c|c|c|c|c|}
\hline & N & Min & Max & M & SD & symmetry & kurtosis \\
\hline winning & 73 & 1.00 & 4.71 & 2.26 & 0.99 & 0.69 & -0.24 \\
\hline avoiding & 73 & 1.00 & 4.86 & 2.39 & 0.89 & 0.39 & 0.06 \\
\hline cooperation & 73 & 1.29 & 5.00 & 3.56 & 0.86 & -0.56 & 0.04 \\
\hline
\end{tabular}

Index: $\quad$ Min=minimum value, $\max =$ Maximum value; $\mathrm{M}=$ mean value; $\mathrm{SD}=$ dispersion from mean value

Composites related to patterns of behaviour in social conflicts were calculated as average values of each subscale/pattern. It is evident from the maximum values (Table 2) that the teachers did not assess any pupil with the maximum value of unconstructive behaviours in the patterns of winning and avoiding. Also, it is evident from the minimum values that no pupil was assessed with the complete absence of constructive behaviours in the pattern of cooperation in social conflicts. The teachers who assessed the behaviour of their pupils in this sample recorded the pattern of winning $(\mathrm{M}=2.26)$ with the average statement "mostly disagree" with the tendency of positive asymmetry. The pattern of avoidance was also assessed $(M=2.39)$ by the average statement "mostly disagree" with a tendency of positive asymmetry. In contrast, the behaviours from the pattern of cooperation were assessed $(\mathrm{M}=3.56)$ on average with answers "neither agree nor disagree" and "mostly agree" with the tendency of negative asymmetry. Deviations from the normal distribution in all three patterns are low. In the assessment of behaviour in the pattern of winning, the answers are more dispersed than in the patterns of avoidance and cooperation. In other words, the teachers gave more diverse answers in the assessment of the patterns of winning shown by their pupils from this sample.

Insight into the intercorrelations of behavioural patterns in social conflicts (Table 3) did not show significant connections in this sample of participants.

The correlates of basic socio-demographic variables with the results on the creativity test and behavior patterns in social conflicts were also analysed. The application of the Spearman rank correlation showed that teacher assessments of pupil behaviour in social conflicts do not correlate significantly with age. Age 
correlates positively and significantly with all creativity scores. The score of convergent-integrative social creativity increases the most with age $(\rho=0.49 ; p<0.01$; $\mathrm{N}=69$ ), while the score of divergent-exploratory social creativity increases the least $(\rho=0.27 ; \mathrm{p}<0.05 ; \mathrm{N}=69)$.

No gender differences were found in the social creativity scores, but they were found in the results on the subscales of patterns of behaviour in social conflicts, similar to previous research (Družinec and Vlah, 2006). On the subscale of winning, the teachers gave significantly higher assessments $(\mathrm{z}=3.811 ; \mathrm{p}<0.001)$ to boys $\left(\mathrm{C}=2.57 ; \mathrm{Q}_{3-1}=1.43\right)$ than girls $\left(\mathrm{C}=1.71 ; \mathrm{Q}_{3-1}=1,00\right)$, while on the subscale of avoidance they gave significantly higher assessments $(\mathrm{z}=2.04 ; \mathrm{p}=0.04)$ to girls $\left(\mathrm{C}=2.64 ; \mathrm{Q}_{3-1}=3.57\right)$ than boys $\left(\mathrm{C}=2.29 ; \mathrm{Q}_{3-1}=1.14\right)$.

All tasks on the $\mathrm{EPoC}$ test of social creativity are designed to measure this unique construct through relevant processes of divergent-exploratory and convergent-integrative thinking and in subdomains with which children have enough experience - relationships in pairs and groups. The measurement carried out on two occasions and by subdomain ensures the reliability of creativity indicators. The mentioned processes of creative thinking, in reality, take place in parallel or rapid succession and are related to the question of the validity of the measure. Such a test structure was confirmed in the drawing and literary domain of creativity and could be repeated in the social domain, which should be empirically verified in the research that is conducted on a larger and more representative sample of participants. High inter-correlations between individual tasks suggest that these are measures whose variability is determined by a unique latent construct of social creativity.

Table 3. Spearman intercorrelations and correlations between potential social creativity and assessed early primary school pupils' patterns of behavior in social conflicts at school

\begin{tabular}{|l|c|c|c|c|c|c|}
\hline & So2Cg1 & So3Dg2 & So4Cd2 & winning & avoiding & cooperation \\
\hline So1Dd1 & $\mathbf{. 3 9} * *$ & $\mathbf{. 7 3 * *}$ & $\mathbf{. 6 7 * *}$ & -.21 & -.07 & .18 \\
\hline So2Cg1 & & $\mathbf{. 7 5 * *}$ & $\mathbf{. 7 6} * *$ & -.05 & $-.26 *$ & .08 \\
\hline So3Dg2 & & & $\mathbf{. 5 9 * *}$ & -.06 & -.11 & .04 \\
\hline So4Cd2 & & & & -.13 & $-.23 *$ & .19 \\
\hline winning & & & & & -.13 & -.22 \\
\hline avoiding & & & & & & -.02 \\
\hline
\end{tabular}

Index: $\quad * * \mathrm{p}<0.01 ; * \mathrm{p}</=0.05$; So1Dd $1=$ divergent-exploratory thinking; So $2 \mathrm{Cg} 1=$ convergent-explorative thinking; So3Dg2= divergent-integrative thinking; So4Cd2= convergent-integrative thinking

Table 3 shows the intercorrelations and correlations of the observed theoretical constructs. Only the points on the convergent-integrative tasks of social creativity 
are negatively associated with avoidance. The correlation with the creativity task in pairs is marginaly significant. Pupils who scored higher on the ability to devise a single, unique, and creative solution to social situations involving pair or group interaction are assessed by teachers as less prone to avoidance strategies. In addition, there is an indication of a low, negative correlation between the pattern of winning and the pattern of collaboration and the pattern of winning and success on all creativity tasks. However, none of these correlations reached the level of statistical significance.

\section{DISCUSSION}

According to the obtained results on individual tasks and scores of potential social creativity, a larger number of results with lower values and a smaller number of high or very high results were determined. Creativity in social situations may be associated with cognitive and social development, so this result is somewhat in line with expectations. However, given that the correlation is higher in the tasks assessed by independent evaluators than in the tasks on which creative products were counted, we can conclude that the evaluators failed to fully contextualize the assessments with respect to the participants' age. The test of potential creativity in the social domain (EPoC-SOC) is at an early stage of development and implementation, and evaluators probably did not have enough experience to control the effect of age and developmentally changing abilities related to creative thinking in the social domain.

The descriptive results of the three patterns of behaviour in social conflicts confirm previous research conducted with pupils of this age in Croatia. These studies found that, in their early primary school teaching, female teachers also assessed that unconstructive patterns of winning and avoiding were used to a lesser extent, while the pupils used collaboration to a greater extent, although still at a mediocre level and insufficiently given how much theoretically it should and could be used (Družinec and Vlah, 2016). Parents assessed their children very low on avoidance, especially low on winning, and medium-high on cooperation (Vlah et al., 2019; Vlah and Nikolić, 2020). Interestingly, by looking at the intercorrelations of behavioural patterns in social conflicts (Table 3), there are no significant correlations in this sample of participants, which refutes previous findings that cooperation and winning were negatively correlated (Družinec and Vlah, 2016; Vlah et al., 2019; Vlah and Nikolić, 2020). However, since this is a relatively small sample, it would be beneficial to verify the indicated correlation tendency on a larger sample.

The observed need to improve pupil competency in the field of conflict behaviour implies that during the developmental age of the participants, socially desirable behaviours are still learned and are not yet mature and adopted in terms of full social competency that can be expected in mature and self-actualized identities. This is part of the conceptual framework of constructive conflict management 
theory, as interpreted by the authors and their proponents (Wilmot and Hocker, 1998; Weeks, 2000; Vlah, 2013). Concrete behaviours in resolving social conflicts that are considered constructive, that is, cooperative ("presents arguments in conversation, explains his/her views, openly states views on the problem, insists on resolving conflicts, motivates associates, asks questions to the interlocutor, and emphasizes the interlocutor's strengths") in the integrated curriculum of the educational institution to encourage and adopt in the classroom, that is, to set their realization and adoption as part of the curriculum goals. This is important because it prepares the child for the future role of a responsible and socially competent citizen who knows, can, and wants to resolve their conflicts constructively and contribute to their living and working environment (Pekrun and Linnenbrink-Garcia, 2014; Hartley, 2016).

Similarly, following the previous findings presented in the Introduction, the following can be implied with regards to personal and general social desirability of learning constructive behaviour in conflicts and insight into assessed pupil behaviours in unconstructive patterns of winning and avoiding. Established behaviours in children such as "uses derogatory words, ridicules the interlocutor, interrupts others, shouts, persistently insists on his demands, pushes the interlocutor away and exclaims: "You started first!" or says "Suit yourself," bows his head during a conversation, feels ashamed, avoids the pupil with whom they are in conflict and says: "It doesn't matter," speaks quietly and is afraid" need to be to neutralize from the child's behaviour, if there are any, through adequate educational procedures.

Of course, it is important to create such child-raising environments where unconstructive behaviours will not even have the opportunity to be learned and realized. However, it is a matter of elaborating on an inclusive and positive school culture when it comes to contemporary educational environments that respect diversity and collaboration (Bouillet, 2019). The interdisciplinary topic of personal and social development for primary schools and grammar schools in the Republic of Croatia (OG 7/2019) mentioned in the Introduction should certainly be one of the relevant ways to promote cooperative and constructive behaviour in social conflicts. Among the educational goals of learning and teaching, it promotes the development of "the image of self-esteem and self-confidence, recognizing, accepting and managing one's emotions and behaviour, and empathy, as well as respecting and accepting diversity, social and communication skills, cooperation and teamwork, responsible behaviour towards oneself and others in the community, decision-making and planning for education, lifelong learning and professional development in modern society and the world of work, problem-solving strategies, and successful coping with stress." The implications of this paper are in line with the objectives of the cross-curricular topic of personal and social development, enabling the development of core competencies and a wide range of knowledge, skills, and attitudes, understanding personal growth and development, developing 
healthy living habits, respecting oneself and others, and understanding the values of harmonious interpersonal relationships. In this way, a self-confident, satisfied, active, and responsible person who takes care of himself and others will be formed, and pupils will adopt general cultural and civilizational values that are a prerequisite for living in a multicultural world. They will manage their living needs and be active members of the family, community, and society (Decision on the adoption of the curriculum on the cross-curricular topic of personal and social development for primary schools and grammar schools in the Republic of Croatia (OG 7/2019). It may also be recommended to conduct social and communication skills training for constructive conflict resolution according to one of the many manuals such as Za Damire i Nemire2 (Uzelac, 2008).

Since the results suggest that the scoring of products on convergent creative tasks was not independent of pupils' age, in future research, standardized results should be used, and it should also be verified whether pupils' age has a significant contribution to explaining the obtained results and correlations as well as whether theoretically expected significant correlations could be obtained after a partialization of the effect of pupils' age. Since teachers have assessed pupils' behaviours in social conflicts, it is legitimate to ask how sensitive they themselves are to know the developmental specifics of their pupils' behaviour in conflicts and whether more attention needs to be paid to their education.

\section{CONCLUSION}

The research aimed to determine the relationship between the potential social creativity of early primary school pupils and their patterns of behaviour in school conflicts. The main results point to the need for further research to replicate the findings on the negative link between social creativity and the pattern of avoidance in social conflicts, as well as recommendations for a curriculum aimed at providing a supportive environment for developing social competency potential and learning constructive, collaborative behaviours in social conflicts.

$\mathrm{EPoC}$ test of potential social creativity is applicable to early primary school pupils and there are indications that it has satisfactory metric characteristics. A positive correlation was found between all test tasks, but the factor structure should be checked on a larger and more representative sample of participants. Also, it should be checked whether the high correlations of test results with the participants' age are due to the connection between cognitive and social development and the potential for creativity in the social domain, or an artifact of insufficient education for scoring products primarily on convergent-integrative test tasks. It has been found that teachers assess children with a higher potential for convergent-integrative creativity as less inclined to use a non-constructive strategy of avoidance.

2 ("For Yes-peaces and No-peaces") 
This paper's special contribution is the use of several methods and sources of information to determine the relationship between social creativity and patterns of behaviour in social conflicts. While most research uses a self-assessment method that is problematic because high correlations may be due to the common method-variance, this research used a test to determine a child's potential creativity and assess a child's behaviour patterns by their classroom teachers. Also, a qualitative methodology of evaluating creative products was used in the method of consensus scoring of evaluators. The significant correlation between potential social creativity and patterns of conflict behavior obtained on a relatively small sample and on different sources of information is the first step in researching this phenomenon and provides guidelines for further improvement of research methodology and new potential correlates in this important domain of development and specific period of child social development.

\section{REFERENCES}

1. Ajduković, M., Pečnik, N. (2007). Nenasilno rješavanje sukoba. Zagreb: Alinea.

2. Amabile, T. M. (1983). The social psychology of creativity: A componential conceptualization. Journal of Personality and Social Psychology, 45(2), 357-376. https:// psycnet.apa.org/record/1984-06764-001

3. Animasahun, R. A. (2008). Predictive Estimates of Emotional Intelligence, Spiritual Intelligence, SelfEfficacy and Creativity Skills on Conflict Resolution Behaviour among the NURTW in South-Western Nigeria. Pakistan Journal of Life and Social Sciences, 6(2), 68-74. https://pdfs.semanticscholar.org/188c/dacaa86a681aaa6ecbce4d734027e43b8953.pdf

4. Arar, Lj., Rački, Ž. (2003). Priroda kreativnosti. Psihologijske teme, 12(1), 3-22. https://hrcak.srce.hr/12733

5. Barbot, B., Besançon, M., Lubart, T. I. (2011). Assessing Creativity in the Classroom. The Open Education Journal, 4, 58-66. https://www.researchgate.net/ publication/256439382_Assessing_Creativity_in the_Classroom

6. Bar-Tal, D. (2011). Introduction: Conflicts and Social Psychology. In I. D. BarTal (Ed.), Integroup Conflicts and Their Resolution: A Social Psychological Perspective, (1-39). New York: Psychology Press.https://scholar.google.hr/scholar?q=Bar-Tal,+D.+(2011).+Introduction:+Conflicts+and+Social+Psychology.\&hl=en\&as_sdt=0\&as_vis $=1 \&$ oi $=$ scholart

7. Bengtsson, M., Raza-Ullah, T., Vanyushyn, V. (2016). The coopetition paradox and tension: The moderating role of coopetition capability. Industrial Marketing Management, 53, 19-30. https:/www.diva-portal.org/smash/get/diva2:902334/ FULLTEXT01.pdf

8. Bouillet, D, (2019). Inkluzivno obrazovanje: odabrane teme. Zagreb: Učiteljski fakultet Sveučilišta u Zagrebu.

9. Brajša, P. (1996). Umijeće svađanja. Pula: C.A.S.H. 
10. Bronfenbrenner, U. (1979). The ecology of human development. Mass.: Harvard University Press https://khoerulanwarbk.files.wordpress.com/2015/08/urie_bronfenbrenner_the ecology_of human_developbokos-z1.pdf

11. Cvetković Lay, J., Sekulić Majurec, A. (2008). Darovito je, što ću s njim?. Zagreb: Alinea. Čudina-Obradović, M. (1991). Nadarenost-razumijevanje, prepoznavanje, razvijanje. Zagreb: Školska knjiga.

12. de Vliert, E. V. (1997). Complex Interpersonal Conflict Behaviour: Theoretical Frontiers. Psychology Press.

13. Deutsch, M., Coleman, P. T., Markus, E. C. (2006). The Handbook of Conflict Resolution. San Francisco: Jossey-Bass.

14. Družinec, V., Vlah, N. (2015). Obrasci ponašanja učenika osnovne škole u sukobima. In D. Maleš, A. Širanović, A. Višnjić Jevtić (Eds.), Pravo djeteta na odgoj i obrazovanja: teorije, politike i prakse (110-119). Zagreb: Filozofski fakultet Sveučilišta u Zagrebu.

15. Dunn, J. (2004). The development of children's conflict and prosocial behaviour: lessons from research on social understanding and gender. In J. Hill, B. Maughan (Eds.), Cambridge child and adolescent psychiatry: Conduct disorders in childhood and adolescence (49-67). University Press.

16. Etički kodeks istraživanja s djecom (2003). Zagreb: Državni zavod za zaštitu obitelji, materinstva i mladeži.

17. Greene, T. R., Noice, H. (1988). Influence of positive affect upon creative thinking and problem solving in children. Psychological Reports, 63(3), 895-898.

18. Grdinić, L., Lončarić, D. (u tisku). Socijalno-interpersonalna kreativnost i faze moralnog rasuđivanja učenika. Zbornik radova s konferencije Darovitost, edukacija darovitih, inovacije i kreativnost u osnovnom, srednjem $i$ visokom obrazovanju i psihologiji.

19. Hartley, J. (2016). A Problem of Knowledge-Solved? In Hartley, J., Hargreaves, I. (Eds) The creative citizen unbound: How social media and DIY culture contribute to democracy, communities and the creative economy, 1-24. Bristol University Press.

20. Ivanova, N., Bikmetova, K. (2017). Identity as a factor of conflict behavior in organizations. DIEM: Dubrovnik International Economic Meeting, 3(1), 34-44.

21. Jurišević, M. (2014). Creativity: An interview with Prof. Todd Lubart on the multivariate approach to creativity. Horizons of Psychology, 23, 168-170. http://psiholoska-obzorja.si/arhiv_clanki/2014/jurisevic_interview.pdf

22. Kim, K. H. (2006). Can We Trust Creativity Tests? A Review of the Torrance Tests of Creative Thinking (TTCT). Creativity Research Journal, 18(1), 3-14. https://www. tandfonline.com/doi/abs/10.1207/s15326934crj1801_2

23. Koizumi, M. (2016). Creativity in a shrinking society: A case study of the water and land Niigata art festival. Cities, 56, 141-147. https://daneshyari.com/article/preview/1008177.pdf

24. Kriesberg, L., Dayton, B. W. (1992). Constructive Conflicts: From escalation to resolution. Rowman and Littlefield Publishers.

25. Kunac, S. (2015). Kreativnost i pedagogija. Napredak, 156(4), 423-446. https://hrcak.srce.hr/166211 
26. Lončarić, D. (2018). Procjena potencijalne kereativnosti djece i adolescenata. Teorijski uvod u primjenu EPoC testa. Izlaganje na edukaciji za primjenu EPoC testa u organizaciji Društva psihologa Istre, 10.-12. travnja 2018, Novigrad, Hrvatska.

27. Lubart, T. I., Besançon, M., Barbot, B. (2011). Evaluation du Potentiel Créatif $(E P o C)$. Editions Hogrefe.

28. Lubart, T. I., Besançon, M., Barbot, B. (2018). EPoC Social-Manuel d'administration. Unpublished manuscript.

29. Lubart, T. (2016). Creativity and convergent thinking: reflections, connections and practical considerations. Journal of Psychology and Pedagogics, 4, 7-15. http://journals.rudn.ru/psychology-pedagogics/article/view/15105

30. Lubart, T. I. (1994). Creativity. In Sternberg R. J. (Ed.), Thinking and Problem Solving, (289-332). Academic Press. https://www.sciencedirect.com/science/article/ pii/B9780080572994500165

31. Lubart, T., Zenasni F., Barbot, B. (2013). Creative Potential and Its Measurement. International Journal for Talent Development and Creativity, 1(2), 41-50. https:// www.academia.edu/22350554/Creative_Potential_and_its_Measurement

32. Maksić, S. (2006). Mjerenje kreativnosti u djetinjstvu i mladosti: Testiranje i procjenjivanje kreativnosti. U S. Krnjajić (ur.), Podsticanje kreativnosti u školi (62-85). Beograd: Institut za pedagoška istraživanja.

33. Mitchell, C. R. (1989). The Structure of International Conflict. Palgrave Macmillan.

34. Mouchiroud, C., Lubart, T. (2002). Social creativity: A cross-sectional study of 6- to 11-year-old children. International Journal of Behavioral Development, 26(1), 60-69. https://journals.sagepub.com/doi/abs/10.1177/016502540202600111

35. Osobni i socijalni razvoj: Odluka o donošenju kurikuluma za međupredmetnu temu Osobni i socijalni razvoj za osnovne i srednje škole u Republici Hrvatskoj. NN 7/2019, (153), odluka, 22.1.2019. Decision on the adoption of the curriculum on the cross-curricular topic of personal and social development for primary schools and grammar schools in the Republic of Croatia (OG 7/2019) https://www.azoo.hr/index. php? view $=$ article\&id $=7161 \&$ naziv $=$ osobni-i-socijalni-razvoj-

36. Pekrun, R., Linnenbrink-Garcia, L. (2014). Introduction to emotions in education. In International handbook of emotions in education (pp. 11-20). Routledge.

37. Puzić, S., Baranović, B., Doolan, K. (2011). Školska klima i sukobi u školi. Sociologija i prostor: časopis za istraživanje prostornoga i sociokulturnog razvoja, 49(3), 335358. https://hrcak.srce.hr/79838

38. Srića, V. (1992). Upravljanje kreativnošću. Zagreb: Školska knjiga.

39. Srića, V. (2003.) Kako postati pun ideja. Zagreb: M.E.P. CONSULT.

40. Sternberg, R. J. (2005). The Theory of Successful Intelligence. Interamerican Journal of Psychology, 39(2), 189-202. http://www.actef.es/sternberg.pdf

41. Sternberg, R. J. (2006). The nature of Creativity. Creativity Resarch Journal, 18(1), 87-98. http://lchc.ucsd.edu/mca/Mail/xmcamail.2010_10.dir/pdfFlf9STmJn3.pdf

42. Sternberg, R. J., Lubart, T. I. (1992). Creativity: Its Nature and Assessment. School Psychology International, 13(3), 243-253. https://journals.sagepub.com/doi/ abs/10.1177/0143034392133004

43. Sternberg, R. J., Lubart, T. I. (2001). Defying the Crowd: Cultivating Creativity in a Culture of Conformity. THE FREE PRESS. 
44. Thillot,M.,Besançon, M.,Lubart,T.(2016).Evaluation ofPotentialCreativity(EPoC):A newSocialCreativityDomain.Retrievedfrom(24.4.2019.)http://search.ebscohost.com/ login.aspx?direct=true \&db=edsbas\&AN=edsbas.44A341CB\&lang=hr\&site=eds-live

45. Torrance, E. P. (1965). Creativity and Learning: Scientific Views of Creativity and Factors Affecting Its Growth. Daedalus, 94(3), 663-668. https:/www.cc.gatech.edu/ classes/AY2018/cs4803cc_spring/research_papers/Torrance-Viewsofcreativity.pdf

46. Torrance, E. P. (1993). Understanding creativity: where to start?. Psychological Inquiry, 4(3), 232-234. http://people.uncw.edu/caropresoe/giftedfoundations/ SocialEmotional/Creativity-articles/Torrance_Understanding-creativity.pdf

47. Uzelac, M. (2008). Za Damire i Nemire. Zagreb: Centar za kulturu mira i nenasilja.

48. Uzelac, S., Bujišić, G. (2014). Osnove socijalne konfliktologije. Zaprešić: Visoka škola za poslovanje i upravljanje "Baltazar Adam Krčelić".

49. Vlah, N. (2013). Poželjna ponašanja mladih u konfliktima. Biakova.

50. Vlah, N., Lovrek, I., Šimunković, G. (2019). Self-AssessmentAnd ParentalAssessment Of Some Risk And Protective Factors By Primary School Pupils. In Blažević I. (Ed.) Proceedings of International scientific conference 18th Mate Demarin Days "New Challenges in Education" Pula (Croatia), May 30. - 31. 2019. In press

51. Vlah, N., Nikolić, A. K. (2020). Obrasci ponašanja u socijalnim sukobima djece prema procjeni njihovih roditelja: doprinos roditeljskih stavova prema ponašanjima $u$ socijalnim sukobima, in press

52. Vlahović-Štetić, V., Vizek Vidović, V., Arambašić, L., Vojnović, N. (2005). Daroviti učenici: teorijski pristup i primjena u školi. Zagreb: Institut za društvena istraživanja, Centar za istraživanja i razvoj obrazovanja.

53. Weeks, D. (2000). Osam najvažnijih koraka u rješavanju sukoba. Osijek: SunceDruštvo za psihološku pomoć.

54. Wilmot, W.W., Hocker, J.L. (1998). Interpersonal conflict. McGraw-Hill.

55. Žitinski, M. (2010). Pluralizam i tranzicijska kultura sukoba-kako s nasiljem?. Obnovljeni život : časopis za filozofiju i religijske znanosti, 65(1), 113-124. https:// hrcak.srce.hr/51563 